\title{
Loci asociados con enfermedades genéticas y calidad de carne en bovinos Charolais mexicanos
}

\section{Loci associated with genetic disorders and meat quality in Charolais cattle in Mexico}

\author{
Ana María Sifuentes Rincóna, Williams Arellano Veraa, Gaspar Manuel Parra \\ Bracamontea, Pascuala Ambriz Moralesa, Luis Arístides López Bustamanteb
}

\begin{abstract}
RESUMEN
Se determinaron las frecuencias alélicas y genotípicas de ocho marcadores localizados en los genes calpaína (CAPN, 4751 y 316), calpastatina (CASTT1) y tiroglobulina (TG5), asociados a calidad de came, y en los genes, miostatina (MSTN, Q204X), arginino succinato sintasa (ASS), monofosfato sintasa (UMPS) y miofosforilasa (PYGM), asociados a enfermedades genéticas de ganado bovino. Se muestrearon 493 animales Charolais de registro de dos hatos ubicados en Sonora $(n=157)$ y tres en Nuevo León $(n=336)$. No se encontraron portadores de los alelos T-ASS y TUMPS, pero sí portadores del alelo Q204X del gen MSTN en frecuencias de $\leq 1 \%$ en las poblaciones de Sonora y de 8.6 a $14.4 \%$ en las de Nuevo León. Además, se identificaron portadores del marcador del gen PYGM, en frecuencias del 6.5 y de $\mathbf{1 . 0} \%$ para un hato de Sonora y otro de Nuevo León, respectivamente. El análisis de diferenciación génica pareado entre las poblaciones y con los cuatro loci mostró que hay diferencias altamente significativas dentro de poblaciones del noroeste $(P<0.0001)$ y entre éstas y las del noreste $(P<0.001)$, la cual es explicada principalmente por los loci CAPN-316 y TG5. De acuerdo a los resultados obtenidos se recomienda el monitoreo del marcador del gen PYGM y del alelo Q204X del gen MSTN, así como también implementar estrategias para confimar la utilidad de los marcadores asociados a calidad y productividad como herramienta para complementar los programas de mejoramiento genético.
\end{abstract}

PALABRAS CLAVE: Defectos genéticos, Marmoleo, Suavidad de la carne, ADN.

\begin{abstract}
Allelic and genotypic frequencies of eight markers previously associated to genetic disorders and meat quality and located in the calpain (CAPN1-4751 and CAPN1-316) , calpastatin (CAST-T1), thyroglobulin (TG5), myostatin (MSTN, Q204X), argininosuccinate synthase (ASS), monophosphate synthase (UMPS) and myophosphorylase (PYGM) genes, were determined from 493 registered Charolais animals sampled from two herds located at Sonora ( $n=157$ ) and three at Nuevo León $(n=336)$, Mexico. No carriers of mutated alleles of ASS and UMPS genes were found, but carriers of the MSTN Q204X allele were identified at frequencies of $\leq 1 \%$ in Sonora populations and 8.6 to $14.4 \%$ in Nuevo Leon. In addition, carriers of PYGM marker were identified at frequencies of 6.49 and $1 \%$ in a herd from Sonora and other from Nuevo León, respectively. Analysis of gene differentiation among herds and with four loci showed that there are highly significant differences within Northwest populations $(P<0.0001)$ and between them and the Northeast $(P<0.001)$, differentiation is mainly explained by the loci CAPN-316 and TG5. According to the obtained results, the periodic monitoring of the PYGM marker gene and of the allele Q204X the MSTN gene is propose; also it is important to implement strategies to confirm the usefulness of those markers associated with quality and productivity as a tool to complement breeding programs.
\end{abstract}

Recibido el 22 de mayo de 2014. Aceptado el 9 de julio de 2014.

a Laboratorio de Biotecnología Animal, Centro de Biotecnología Genómica. Instituto Politécnico Nacional. Boulevard del Maestro esq. Elías Piña S/N, Col. Narciso Mendoza, 88710 Cd. Reynosa, Tamaulipas, México. Tel: (899) 92436 27. asifuentes@ipn.mx. Correspondencia al primer autor.

b Charolais Herd Book de México A.C. Comité Técnico. México.

Proyecto apoyado por fondos FORDECYT y FOMIX Tamaulipas 177460. 
KEY WORDS: Genetic defects, Marbling, Tenderness, DNA.

\section{INTRODUCCIÓN}

Actualmente, las pruebas de ADN son herramientas disponibles para los criadores de ganado y todos aquellos interesados en llevar a cabo el monitoreo de la calidad y salud genética de los animales del hato(1,2). En bovinos, se han descrito pruebas de ADN para identificar portadores de al menos 40 desórdenes genéticos $(1,3)$.

En el caso de la raza Charolais, diferentes Asociaciones en el mundo reportan oficialmente el fenotipo doble músculo (DM). Esta es una condición genética que es producto de mutaciones disruptivas en el gen de la miostatina (MSTN) (4). Además del fenotipo DM, otros desórdenes genéticos reportados para la raza Charolais son la Citrulinemia bovina (ASS), la Enfermedad de Almacenamiento del Glucógeno tipo V (EAG-V), y la Deficiencia de la Uridina 5 Monofosfato Sintasa (DUMPS); todos estos desórdenes son recesivos y son causados por mutaciones en genes específicos(5).

En el caso de las pruebas de ADN para predecir la calidad de la carne y la productividad, las que a la fecha han alcanzado mayor difusión son las de rasgos sensoriales de la carne(6), específicamente suavidad y contenido de grasa intramuscular (marmoleo). El marcador TG5 del gen tiroglobulina, es una transición $\mathrm{C} / \mathrm{T}$ localizada en el sitio consenso de unión de la RNA polimerasa III, 537 pb río arriba del inicio del primer exón del gen de tiroglobulina (NW_001493192.1.g.290170C>T). El polimorfismo de este marcador está definido por los alelos 2 y 3, mientras que el alelo 2 muestra la secuencia GATC, y el alelo 3 tiene una secuencia GATT, el cual se ha asociado a mayor marmoleo. Aunque ya hay estudios en los que se ha validado su asociación a marmoleo(6), hay reportes en los que no se ha encontrado efecto significativo sobre la característica(7). Para suavidad 0 terneza, dos marcadores localizados en el gen de la micro-calpaína 1 (CAPN1-316 y CAPN1-

\section{INTRODUCTION}

For cattle producers and all those interested in monitoring animal quality and genetic health, DNA testing is a widely available and important tool $(1,2)$. To date, DNA tests have been done identifying carriers of at least 40 genetic disorders in cattle $(1,3)$. In the Charolais breed, different cattle associations worldwide have reported the double muscle (DM) phenotype, a genetic condition produced by disruptive mutations in the myostatin gene (MSTN)(4). Additional disorders reported for the Charolais breed include bovine citrullinemia (argininosuccinate synthetase - ASS); type-V glycogen storage disease (GSD-V); and uridine-5'-monophosphate synthase deficiency (UMSD). All these disorders are recessive and caused by mutations in specific genes(5).

Among DNA tests currently used to predict meat quality and animal productivity, the most common are those focused to meat sensory features, such as tenderness and intermuscular fat content (marbling). The TG5 marker of the thyroglobulin gene is a C/T transition at the union consensus site of the RNA polymerase III, 537 bp upstream from the beginning of the thyroglobulin gene's first exon (NW_001493192. 1.g. $290170 \mathrm{C}>\mathrm{T}$ ). This marker's polymorphism is defined by alleles 2 and 3; allele 2 exhibits the GATC sequence while allele 3 has a GATT sequence (associated with greater marbling). Some studies have validated an association with marbling(6), while others report no significant effect on this trait(7). For tenderness, two markers localized in the micro-calpain 1 gene (CAPN1-316 and CAPN1-4751), and two others in the calpastatine gene (CAST) have received the most attention and have a validated effect on tenderness(6). The marker CAPN1-316 is a $\mathrm{G} / \mathrm{C}$ transversion at position 5709 of exon 9 in the CAPN1 gene, while CAPN1-4751 is a localized C/T transition at position 6545 between intron 17 and 18 of the same gene(6). In both markers, the $C$ allele has been reported and validated as favoring meat tenderness(6). The marker UoG CAST is a $\mathrm{G} / \mathrm{C}$ transversion at 
4751) y dos ubicados en el gen de la calpastatina (CAST), son a la fecha los más estudiados y su efecto sobre la suavidad ha sido validado(6). El marcador CAPN1-316, es una transversión $\mathrm{G} / \mathrm{C}$ en la posición 5709 del exón 9 del gen CAPN1, mientras que el marcador CAPN1-4751 es una transición de C/T localizada en la posición 6545 entre el intrón 17 y el exón 18 del mismo gen(6). En ambos marcadores el alelo $\mathrm{C}$ ha sido reportado y validado como favorable para la suavidad de la carne(6). El marcador UoG CAST es una transversión G/C que se encuentra en la posición 282 entre el exón 5 y 6 y el CAST-T1 es una transición G/A localizada la región $3^{\prime}$ no traducible del gen. Los alelos $\mathrm{C}$ y $\mathrm{A}$, respectivamente se han identificado como favorables para la suavidad de la carne en bovinos.

En este trabajo se tipificaron poblaciones de ganado Charolais de registro, utilizando un panel de marcadores asociados con enfermedades genéticas y con rasgos sensoriales de la carne, con el fin de determinar sus frecuencias alélicas y conocer el potencial genético-molecular de las poblaciones estudiadas.

\section{MATERIALES Y MÉTODOS}

Utilizando el estuche comercial Promega Wizard, se realizó la extracción de ADN a muestras de sangre de 493 animales provenientes de cinco ranchos de registro de ganado Charolais. Dos de ellos localizados en Sonora, región noroeste de México, SoR1 $(n=83)$ y SoR2 $(n=74)$, y tres en la región noreste del estado de Nuevo León, NLR1 $(n=79), \operatorname{NLR2}(n=100)$ y NLR3 $(n=157)$. Con excepción de 21 muestras de machos, todas las muestras fueron de hembras.

Las muestras se tipificaron por discriminación alélica con los marcadores CAPN1-316 (transversión G/C), CAPN1-4751 (transición de C/T), CAST-T1 (transición A/G) y alelo Q204X (transición $\mathrm{C} / \mathrm{T}$ ), utilizando los iniciadores y sondas específicos para cada SNP (Cuadro 1), las cuales se sintetizaron en la compañía Applied Biosystems. Todos los ensayos se realizaron en position 282 between exons 5 and 6, and the CAST-T1 marker is a localized G/A transition in the gene's untranslatable $3^{\prime}$ region. Allele $C$ in UoG CAST, and allele A in CAST-T1 have been identified as favoring meat tenderness in cattle.

The present study objective was to typify registered Charolais cattle populations from Northwest and Northeast Mexico, using a SNPs panel associated with genetic diseases and meat sensory traits in order to determine their allele frequencies and understand their molecular genetic potential.

\section{MATERIALS AND METHODS}

Blood samples were taken from cattle at five registered Charolais breed ranches: two in the state of Sonora (SoR1 [n=83]; SoR2 [n=74]) in northwest Mexico, and three in the state of Nuevo Leon (NLR1 [ $n=79]$; NLR2 [ $n=100]$; NLR3 [ $n=157]$ ) in the country's northeast. Total sample size was 493 (21 bulls, 472 cows).

A Wizard ${ }^{\circledR}$ Genomic DNA Purification kit (Promega, Madison, WI, USA) was used to extract DNA from the blood samples. These were typified by allelic discrimination using the markers CAPN1-316 (G/C transversion), CAPN14751 (C/T transversion) and CAST-T1 (A/G transition), the allele Q204X (C/T transition), and primers and probes specific to each single nucleotide polymorphism (SNP) (Applied Biosystems, Mexico City, Mexico) (Table 1). Analysis was done using $250 \mathrm{ng}$ DNA, $12.5 \mu \mathrm{l}$ Taqman PCR master mix (Applied Biosystems), and $0.625 \mu \mathrm{l}$ primer and probe mixture (Assay SNP mix). All assays were achieved in a thermocycler (ABI Prism 7000 Sequence Detection System) under the following conditions: $50{ }^{\circ} \mathrm{C}$ for $2 \mathrm{~min}$; $95{ }^{\circ} \mathrm{C}$ for $10 \mathrm{~min}$; and 40 two-step cycles of $92{ }^{\circ} \mathrm{C}$ for $15 \mathrm{~s}$ and $60{ }^{\circ} \mathrm{C}$ for $1 \mathrm{~min}$. Genotype identification for each marker was done with the ABI Prism 7000 Sequence Detection System software.

Samples were also typified using four markers in PCR-RFLP assays. The specific primer 
Ana María Sifuentes Rincón, et al. / Rev Mex Cienc Pecu 2015;6(4):361-375

Cuadro 1. Iniciadores y sondas específicos para los marcadores Q204X, CAPN1-316, CAPN1-4751 y CAST-T1

Table 1. Primers and probes specific to markers Q204X, CAPN1-316, CAPN1-4751 and CAST-T1

\begin{tabular}{lll}
\hline Marker & Primers $\left(5^{\prime}-3^{\prime}\right)$ & Probes \\
\hline Q204X & F-GGAATCCGATCTCTGAAACTTGACA & VIC-CAATGCTCTGCCAAATA \\
& R-GCTCTGCAACACTGTCTTCAC & FAM-ATCAATGCTCTACCAAATA \\
CAPN1-316 & F-GCAGTGCCGTTTTCCTACAG & VIC-CCACGGCGTTCCA \\
& R-AGCTGCTCCCGCATGTAAG & FAM-CCACGCCGTTCCA \\
CAPN1-4751 & F-TGGCATCCTCCCCTTGACT & VIC-CTGCGCCTCTGTTT \\
& R-CCCCCGTCACTTGACACA & FAM-CTGCGCCTCCGTTT \\
CAST-T1 & F-CTCACGTGTTCTTCAGTGTTCTG & VIC-CCTTTCCTCTTAGACTTGT \\
& R-CAACCCAAAGAAACATCAAACACAGT & FAM-CTTTCCTCTTGGACTTGT \\
\hline
\end{tabular}

el equipo ABI Prism 7000 Sequence Detection System, utilizando las siguientes condiciones: un ciclo de $2 \min$ a $50{ }^{\circ} \mathrm{C}$ y $10 \min$ a $95^{\circ} \mathrm{C}$, seguido de 40 ciclos de dos pasos $15 \mathrm{~s}$ a 92 ${ }^{\circ} \mathrm{C}$ y 1 min a $60{ }^{\circ} \mathrm{C}$. Se utilizaron $250 \mathrm{ng}$ ADN, $12.5 \mu \mathrm{l}$ of Taqman PCR master mix (Applied Biosystems), y $0.625 \mathrm{ml}$ de la mezcla de sondas e iniciadores (Assay SNP mix). La llamada de los genotipos para cada marcador se llevó a cabo utilizando el software ABI Prism 7000 Sequence Detection System.

Adicionalmente, las muestras se tipificaron con cuatro marcadores mediante ensayos de PCRRFLP; para estos, las secuencias de los iniciadores y las enzimas de restricción específicas para detectar el SNP se tomaron de la literatura y se describen a continuación. La PCR para el marcador TG5 se realizó utilizando los iniciadores TG5U2 5' ggg gat gac tac gag tat gac tg 3' y TG5D1 5' gtg aaa atc ttg tgg agg ctg ta3' que generan un fragmento de $545 \mathrm{pb}^{(8)}$, la transición $\mathrm{C} / \mathrm{T}$ se identificó después de digerir el fragmento con la enzima Mbo I, el alelo 2 produce fragmentos de $17 \mathrm{pb}$, 73 pb, 177 pb y 278 pb mientras que el alelo 3 se caracteriza por el patrón de bandas de 73 pb, 194 pb y 278 pb. Para el marcador asociado a la EAG-V, se usaron los iniciadores reportados F-5' -CCA GGA AGA CCC TCA TTC CA-3 y R-5' AGG GAA ACA CAC ACA CAG-3’(5). La transición sequences and restriction enzymes for SNPs detection were taken from the literature. The PCR runs for marker TG5 were done using the primers TG5U2 5'ggg gat gac tac gag tat gac tg 3' and TG5D1 5'gtg aaa atc ttg tgg agg ctg ta3', which generate a 545 bp fragment. The $\mathrm{C} / \mathrm{T}$ transition was identified after digestion with the Mbo I enzyme. Allele 2 produces 17, 73, 177 and 278 bp fragments, while Allele 3 is characterized by a 73, 194 and $278 \mathrm{bp}$ band pattern. For the GSD-V marker, the primers F-5'-CCA GGA AGA CCC TCA TTC CA-3' and R-5'-AGG GAA ACA CAC ACA CAG-3' were used(5). The $C / T$ transition in codon 489 of the myophosphorylase gene was detected with the Sty I enzyme. A band pattern of 119 and 133 bp was used to identify the TT homozygotic carriers, and a 252 bp pattern used for unaffected CCs. Markers associated with DUMPS were typified with the primers DUMPS-F 5'-GCA AAT GGC TGA AGA ACA TTC TG-3' and DUMPS R 5'-GCT TCT AAC TGA ACT CCT CGA GT-3', while for ASS ASS-F 5'-GTG TTC ATT GAG GAC ATC-3' and ASS-R 5'-CCG TGA GAC ACA TAC TTG-3 were used(5).

The $\mathrm{C} / \mathrm{T}$ transition in the uridine-5'monophosphate synthase associated with DUMPS was identified with the Ava I enzyme in which normal homozygotes exhibit a pattern of 
C/T en el codón 489 del gen de la miofosforilasa fue detectada con la enzima Sty I, donde los portadores homocigotos $\pi T$ fueron identificados por un patrón de bandas de 133 pb y 119 pb y los no afectados CC una banda de 252 pb. Los marcadores asociados a DUMPS y ASS se tipificaron utilizando los iniciadores DUMPS- $F$ 5'-GCA AAT GGC TGA AGA ACA TTC TG-3': DUMPS_R 5'-GCT TCT AAC TGA ACT CCT CGA GT-3' y ASS-F 5' -GTG TTC ATT GAG GAC ATC-3, ASS-R 5'-CCG TGA GAC ACA TAC TTG-3, respectivamente(5).

La transición $(\mathrm{C} / \mathrm{T})$ en el gen de uridina monofosfato sintasa asociado a la DUMPS, se detectó con la enzima Ava I, donde los homocigotos normales muestran un patrón de bandas de 23, 36 y 19 pb y los homocigotos recesivos de 89 y 19 pb. Mientras que para la ASS la transición C/T del codón 86 de la proteína del gen ASS se detectó con la enzima Ava II, donde un producto sin digerir identifica a los portadores mutados y un patrón de bandas de 118 y 80 pb a los portadores no afectados(5).

Todas las amplificaciones se realizaron en un volumen de $12.5 \mu \mathrm{l}$ utilizando $50 \mathrm{ng}$ de ADN, $2 \mathrm{mM}$ de $\mathrm{MgCl}_{2}, 0.25 \mu \mathrm{M}$ de cada iniciador $\mathrm{y}$ $0.125 \mathrm{U}$ de GoTaq DNA polimerasa. Para las amplificaciones se utilizó un perfil de temperaturas tipo "touchdown" que consistió en incubación a 95으 $\mathrm{C} 10^{\prime}, 5$ ciclos de $95^{\circ} \mathrm{C} / 45^{\prime \prime}$, $65^{\circ} \mathrm{C} / 45^{\prime \prime}$ (disminuyendo $2^{\circ} \mathrm{C}$ cada ciclo) y $72^{\circ} \mathrm{C}$ $45^{\prime \prime}$; posteriormente 25 ciclos a $95^{\circ} \mathrm{C} / 45^{\prime \prime}, 60^{\circ} \mathrm{Cl}$ $45^{\prime \prime}$ y $72^{\circ} \mathrm{C} / 45^{\prime \prime}$, finalmente a $72^{\circ} \mathrm{C} / 10^{\prime}$. La amplificación se confirmó por electroforesis en un gel de agarosa al 1.5\% teñido con Syber Gold, posteriormente se visualizó en el fotodocumentador Kodak Gel Logic 112.

Las digestiones enzimáticas se realizaron utilizando $10 \mu \mathrm{l}$ del producto de PCR y $2.5 \mathrm{U}$ de enzima de restricción específica para cada polimorfismo; los patrones de bandeo de la digestión se analizaron por electroforesis en geles de agarosa Nusieve al $4.5 \%$, la cual se preparó siguiendo las instrucciones de la casa bands at 23, 36 and $19 \mathrm{bp}$, and recessive homozygotes have a pattern with 89 and 19 bp. For ASS, the C/T transition of codon 86 in the ASS gene protein was identified with the Ava II enzyme in which an indigested product indicated mutated carriers, and bands at 118 and $80 \mathrm{bp}$ identified unaffected carriers(5).

All amplifications were done in a $12.5 \mu \mathrm{l}$ final volume containing $50 \mathrm{ng}$ DNA, $2 \mathrm{mM} \mathrm{MgCl}$, $0.25 \mu \mathrm{M}$ of each primer, and $0.125 \mathrm{U}$ GoTaq DNA polymerase. A touchdown temperature profile was used in the assay: $95{ }^{\circ} \mathrm{C}$ for $10 \mathrm{~h}$; 5 cycles at $95{ }^{\circ} \mathrm{C}$ for $45 \min 65{ }^{\circ} \mathrm{C}$ for $45 \mathrm{~min}$ (decreasing $2{ }^{\circ} \mathrm{C}$ per cycle) and $72{ }^{\circ} \mathrm{C}$ for 45 min; 25 cycles at $95{ }^{\circ} \mathrm{C}$ for $45 \mathrm{~min}, 60^{\circ} \mathrm{C}$ for 45 min and $72{ }^{\circ} \mathrm{C}$ for $45 \mathrm{~min}$; and $72{ }^{\circ} \mathrm{C}$ for $10 \mathrm{~h}$. Amplification was confirmed by electrophoresis in $1.5 \%$ agarose gel stained with SYBER ${ }^{\circledR}$ Gold; gels were viewed in a photodocumentor (Gel Logic 112, Kodak).

Enzymatic digestions were done using $10 \mu \mathrm{l}$ PCR product and $2.5 \mathrm{U}$ restriction enzyme specific to each polymorphism. Digestion band patterns were analyzed with electrophoresis in 4.5\% Nusieve agarose gel prepared following manufacturer instructions (Karlan Research Products Co., Phoenix, AZ, USA).

Genotype and allele frequencies were then estimated with the Cervus 3.0 program( ${ }^{(9)}$. Using the Genepop 4.2 program(10), Hardy-Weinberg equilibrium (HWE) was calculated, and genetic differentiation between the studied populations was analyzed for the four meat qualityassociated markers. In the genetic differentiation analysis, the tested null hypothesis was $\mathrm{Ho}=$ allele distribution identical across populations. For populations, the test was done automatically by pairs of populations using contingency tables. A non-biased estimate of the $P$ value or a Fischer exact test was run(10). Graphic illustration of differentiation by allele segregation among these markers was done with a correspondence analysis in the SAS ver. 9.0 program (SAS Institute Inc., Cary, NC, USA). 
Ana María Sifuentes Rincón, et al. / Rev Mex Cienc Pecu 2015;6(4):361-375

Cuadro 2. Frecuencias alélicas y genotípicas de los cuatro marcadores asociados a enfermedades genéticas y calidad de carne en ganado Charolais de registro (\%)

Table 2. Allele and genotype frequencies of four markers associated with genetic disorders and four associated with meat quality in registered Charolais cattle (\%)

\begin{tabular}{|c|c|c|c|c|c|c|c|}
\hline \multirow[b]{2}{*}{ Marker } & \multirow[b]{2}{*}{ SNP* $^{*}$} & \multirow[b]{2}{*}{ Population } & \multicolumn{3}{|c|}{ Genotype } & \multicolumn{2}{|c|}{ Allele } \\
\hline & & & 1 & 12 & 2 & 1 & 2 \\
\hline Q204X & $\mathrm{T} / \mathrm{C}$ & $\begin{array}{l}\text { SoR1 } \\
\text { SoR2 } \\
\text { NLR1 } \\
\text { NLR2 } \\
\text { NLR3 }\end{array}$ & $\begin{array}{c}100 \\
98.64 \\
85.54 \\
89.8 \\
91.37\end{array}$ & $\begin{array}{c}0 \\
1.35 \\
14.45 \\
10.20 \\
8.62\end{array}$ & $\begin{array}{l}0 \\
0 \\
0 \\
0 \\
0\end{array}$ & $\begin{array}{c}1 \\
0.066 \\
0.0723 \\
0.0510 \\
0.0449\end{array}$ & $\begin{array}{c}0 \\
0.934 \\
0.9277 \\
0.9490 \\
0.9551\end{array}$ \\
\hline GDS-V & $\mathrm{C} / \mathrm{T}$ & $\begin{array}{l}\text { SoR1 } \\
\text { SoR2 } \\
\text { NLR1 } \\
\text { NLR2 } \\
\text { NLR3 }\end{array}$ & $\begin{array}{c}100 \\
93.43 \\
100 \\
99.01 \\
100\end{array}$ & $\begin{array}{c}0 \\
6.57 \\
0 \\
0.99 \\
0\end{array}$ & $\begin{array}{l}0 \\
0 \\
0 \\
0 \\
0\end{array}$ & $\begin{array}{c}1 \\
0.100 \\
1 \\
0.01 \\
0\end{array}$ & $\begin{array}{c}0 \\
0.8998 \\
0 \\
0.9999 \\
1\end{array}$ \\
\hline DUMPS & $\mathrm{C} / \mathrm{T}$ & $\begin{array}{l}\text { SoR1 } \\
\text { SoR2 } \\
\text { NLR1 } \\
\text { NLR2 } \\
\text { NLR3 }\end{array}$ & $\begin{array}{l}100 \\
100 \\
100 \\
100 \\
100\end{array}$ & $\begin{array}{l}0 \\
0 \\
0 \\
0 \\
0\end{array}$ & $\begin{array}{l}0 \\
0 \\
0 \\
0 \\
0\end{array}$ & $\begin{array}{l}0 \\
0 \\
0 \\
0 \\
0\end{array}$ & $\begin{array}{l}1 \\
1 \\
1 \\
1 \\
1\end{array}$ \\
\hline ASS & $\mathrm{C} / \mathrm{T}$ & $\begin{array}{l}\text { SoR1 } \\
\text { SoR2 } \\
\text { NLR1 } \\
\text { NLR2 } \\
\text { NLR3 }\end{array}$ & $\begin{array}{l}100 \\
100 \\
100 \\
100 \\
100\end{array}$ & $\begin{array}{l}0 \\
0 \\
0 \\
0 \\
0\end{array}$ & $\begin{array}{l}0 \\
0 \\
0 \\
0 \\
0\end{array}$ & $\begin{array}{l}0 \\
0 \\
0 \\
0 \\
0\end{array}$ & $\begin{array}{l}1 \\
1 \\
1 \\
1 \\
1\end{array}$ \\
\hline CAST-T1 & $\mathrm{A} / \mathrm{G}$ & $\begin{array}{l}\text { SoR1 } \\
\text { SoR2 } \\
\text { NLR1 } \\
\text { NLR2 } \\
\text { NLR3 }\end{array}$ & $\begin{array}{l}89.5 \\
96.4 \\
44.8 \\
64.4 \\
80.4\end{array}$ & $\begin{array}{c}9.2 \\
3.6 \\
47.5 \\
26.7 \\
19\end{array}$ & $\begin{array}{c}1.31 \\
0 \\
7.7 \\
8.9 \\
0.6\end{array}$ & $\begin{array}{l}0.9400 \\
0.9769 \\
0.6859 \\
0.7750 \\
0.8994\end{array}$ & $\begin{array}{l}0.0600 \\
0.0231 \\
0.3141 \\
0.2250 \\
0.1006\end{array}$ \\
\hline CAPN316 & $\mathrm{C} / \mathrm{G}$ & $\begin{array}{l}\text { SoR1 } \\
\text { SoR2 } \\
\text { NLR1 } \\
\text { NLR2 } \\
\text { NLR3 }\end{array}$ & $\begin{array}{c}3.0 \\
5.1 \\
2.5 \\
18.4 \\
0\end{array}$ & $\begin{array}{c}23.3 \\
6.4 \\
26.5 \\
3 \\
60.8\end{array}$ & $\begin{array}{c}73.7 \\
88.5 \\
71 \\
78.6 \\
39.2\end{array}$ & $\begin{array}{l}0.1333 \\
0.0844 \\
0.1582 \\
0.7921 \\
0.6960\end{array}$ & $\begin{array}{l}0.8667 \\
0.9156 \\
0.8418 \\
0.2079 \\
0.3040\end{array}$ \\
\hline CAPN1-4751 & $\mathrm{C} / \mathrm{T}$ & $\begin{array}{l}\text { SoR1 } \\
\text { SoR2 } \\
\text { NLR1 } \\
\text { NLR2 } \\
\text { NLR3 }\end{array}$ & $\begin{array}{c}18.4 \\
26.1 \\
24 \\
17 \\
22.9\end{array}$ & $\begin{array}{c}55.3 \\
43.8 \\
53.2 \\
50 \\
44\end{array}$ & $\begin{array}{c}26.3 \\
30.1 \\
22.8 \\
33 \\
33.1\end{array}$ & $\begin{array}{l}0.5400 \\
0.5156 \\
0.5063 \\
0.5879 \\
0.5514\end{array}$ & $\begin{array}{l}0.4600 \\
0.4844 \\
0.4937 \\
0.4121 \\
0.4486\end{array}$ \\
\hline TG5 & $\mathrm{T} / \mathrm{C}$ & $\begin{array}{l}\text { SoR1 } \\
\text { SoR2 } \\
\text { NLR1 } \\
\text { NLR2 } \\
\text { NLR3 }\end{array}$ & $\begin{array}{c}27.7 \\
5.1 \\
5.12 \\
6.3 \\
24.2\end{array}$ & $\begin{array}{c}19.4 \\
17.9 \\
39 \\
29.4 \\
15\end{array}$ & $\begin{array}{l}52.8 \\
76.9 \\
55.1 \\
64.2 \\
60.8\end{array}$ & $\begin{array}{l}0.3803 \\
0.1429 \\
0.2500 \\
0.2105 \\
0.3152\end{array}$ & $\begin{array}{l}0.6197 \\
0.8571 \\
0.7500 \\
0.7895 \\
0.6848\end{array}$ \\
\hline
\end{tabular}

*Single nucleotide polymorphisms: $1 / 2$. 
comercial (Karlan Research Products Corporation, Phoenix, AZ 85070).

Posteriormente, se estimaron las frecuencias genotípicas y alélicas de los ocho marcadores analizados utilizando el programa Cervus 3.0(9). Se analizó el equilibrio de Hardy-Weinberg (HWE) y se evaluó la diferenciación genética entre las poblaciones de estudio para los cuatro marcadores asociados a calidad de la carne, utilizando el programa Genepop 4.2(10). En el análisis de diferenciación genética, la hipótesis nula probada fue $\mathrm{Ho}=$ la distribución alélica es idéntica a través de las poblaciones. Para poblaciones, la prueba se realiza automáticamente por medio de tablas de contingencia por pares de poblaciones, y se lleva a cabo una estimación no sesgada del valor de P prueba exacta de Fisher como la describen Raymond y Rousset(10). Para ilustrar gráficamente la diferenciación por segregación alélica en estos marcadores se realizó un análisis de correspondencia utilizando el programa SAS ver. 9.0 (SAS Institute Inc., Cary, NC, USA).

\section{RESULTADOS}

Marcadores asociados a desórdenes genéticos

En las poblaciones estudiadas, no se encontraron portadores de los alelos asociados

\section{RESULTS}

Markers associated with genetic disorders No carriers of ASS- or DUMPS-associated alleles were identified in the present data. However, some carriers were identified of genetic variants associated with GDS-V and DM (Table 2). Allele Q204X is associated with DM and was found in $28(5.87 \%)$ cows with frequencies in different herds varying from 0 to $14.4 \%$.

When analyzed by region, the ranches in northeast Mexico had higher Q204X frequencies (8.6 to $14.4 \%$ ) than those in the northwest (maximum frequencies $=1 \%$ ). This discrepancy may be due to the source of the genetic material used in herd improvement. It is common in the northeast, particularly in the analyzed herds, to use European genetic material (mainly French semen). In some studies, carrier sire frequency is as high as $27 \%(11,12)$. To support this result, the pedigree data for the carrier cows identified in the study allowed them to be grouped into six families of half-sisters with French fathers. A biological sample was acquired from these French sires and DNA testing confirmed them to be Q204X carriers.

Five cows and one bull were also found to carry the GDS-V-associated marker (Figure 1).

Figura 1. Detección de portadores de la EAG-V. Se muestran los resultados de PCR-RFLP de individuos de la población SoR2

Figure 1. Identification of GDS-V carriers. PCR-RFLP results for individuals in SoR2 population

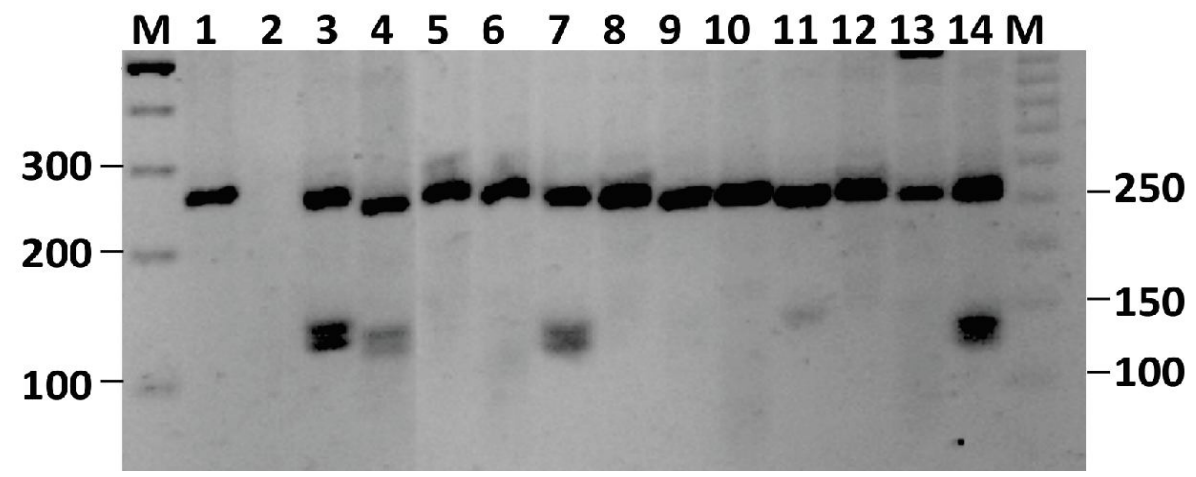

Rows $3,4,7$ and 14 exhibit the 252, 133 and 119 bp pattern corresponding to carriers of the GDS-V associated allele in this population. Row $1=$ undigested PCR product; $\mathrm{M}=$ marker for 300,200 and $100 \mathrm{bp}$ molecular weights. 
a ASS y DUMPS. Sin embargo, se encontraron animales portadores para las variantes génicas asociadas a la EAG- $\mathrm{V}$ y al doble músculo (Cuadro 2). Para el alelo Q204X asociado al doble músculo, se encontraron en la población total 28 hembras portadoras (5.87\%) y entre hatos las frecuencias de portadoras variaron entre 0 a $14.4 \%$.

El análisis por región permitió observar que los hatos ubicados en la región noreste de México, tienen mayores frecuencias del alelo Q204X (8.6 a $14.4 \%)$ respecto a las localizadas en el noroeste, que mostraron una máxima frecuencia de $1 \%$. Este resultado podría explicarse por el origen del material genético con el que se mejoran estos hatos, ya que es común que en el noreste y en particular en los hatos analizados, la fuente de material genético sea europeo (principalmente semen Francés), y la frecuencia de sementales portadores reportadas para este alelo en algunos estudios es hasta del $27 \%(11,12)$. Para apoyar este resultado, con la información de pedigrí de las hembras portadoras identificadas en el estudio, se lograron formar seis familias de medias hermanas cuyos padres son de origen francés. De estos últimos se logró obtener una muestra biológica y la prueba de ADN confirmó que estos son portadores del alelo Q204X.

En el estudio también se encontraron cinco hembras y un macho portadores del marcador asociado a la EAG-V (Figura 1). En este caso la mayor frecuencia se registró en un hato del noroeste $(6.49 \%)$, y sólo una portadora en un hato del noreste (1 \%). La verificación del pedigrí de dos de las vacas portadoras permite suponer que es posible que el alelo haya sido transmitido por vía paterna, de un semental proveniente de Estados Unidos no incluido en este estudio.

Marcadores asociados a calidad de carne

En la Cuadro 2 se muestran las frecuencias alélicas y genotípicas de los cuatro marcadores
The highest frequency $(6.49 \%)$ was recorded in a herd in the northwest, with only one carrier in the northeast ( $1 \%$ ). Pedigree verification of two of the cows carrying this allele suggested it had been transmitted through the paternal line from a sire in the United States that was not included in this study.

Markers associated with meat quality

Paired genetic differentiation analysis between populations using the four analyzed loci showed highly significant differences within the two populations in the northwest $(P<0.0001)$, and between these two populations and the three in the northeast $(P<0.001)$ (Table 2$)$. In the northeast, population NLR3 differed from the other two northeast populations (NLR1 and NLR2). Analysis by loci identified a differences between the four markers. The most significant was in the TG5 marker between SoR1 and SoR2, and between these two populations and NLR3. No differences between the populations were observed in marker 4751.

Allele segregation identified a strong influence from markers CAPN1-316 and CAST-T1 in differentiation between the northeast and northwest herds (Figure 2). It also indicated variability for the analyzed loci to be lowest among the two northwest herds.

In the expected and observed heterozygosity data (Table 3), only two markers exhibited deviation in HWE. For TG5, this deviation was significant in the two northwest herds and NLR3, while for CAPN316 it was significant for SoR1, NLR2 and NLR3. All deviations were caused by a heterozygote deficit.

\section{DISCUSSION}

Markers associated with genetic diseases

Cattle associations worldwide officially recognize genetic disorders in different cattle breeds and record them in animal registers. This is vital data that can be made available to animal and semen buyers, allowing them to exclude affected 
asociados a calidad de la carne. El análisis de diferenciación génica pareado entre las poblaciones y con los cuatro loci mostró que hay diferencias altamente significativas dentro de las dos poblaciones del noroeste $(P<0.0001)$ $\mathrm{y}$ entre estas dos poblaciones y las tres del noreste $(P<0.001)$. Adicionalmente entre poblaciones, la población NLR3 fue significativamente diferente de las otras dos poblaciones del noreste (NLR1 y NLR2). El análisis por loci demostró que existe diferente comportamiento para los cuatro marcadores, siendo las diferencias más significativas en el marcador TG5 entre las poblaciones del noroeste y estas dos poblaciones y la NLR3. En el marcador 4751 no se observaron diferencias significativas entre las cuatro poblaciones. A nivel de segregación alélica la Figura 2 muestra una fuerte influencia de los alelos del marcador CAPN1-316 y CAST-T1 en la diferenciación de los hatos del noreste contra los del noroeste, e indica una menor variabilidad entre los hatos de esta última región para los loci analizados.

En el Cuadro 3 se muestran las heterocigosidades esperadas y observadas; sólo en dos marcadores se observó desviación al equilibrio HardyWeinberg. La desviación al EHW fue significativa para el marcador TG5 en las dos poblaciones del noroeste y la población NLR3 del noreste, mientras que en el marcador CAPN316 lo fue en la población SoR1 del noroeste y dos animals from breeding or adequately manage them within a herd. In this way, cattle associations can control dissemination of compromised genetic material and eventually eliminate carriers from the gene pool.

Figura 2. Gráfico factorial de correspondencia de segregación alélica de marcadores asociados a calidad de la carne en hatos del noroeste y noreste de México

Figure 2. Allele segregation of markers associated with meat quality in herds of Charolais cattle in northwest and northeast Mexico

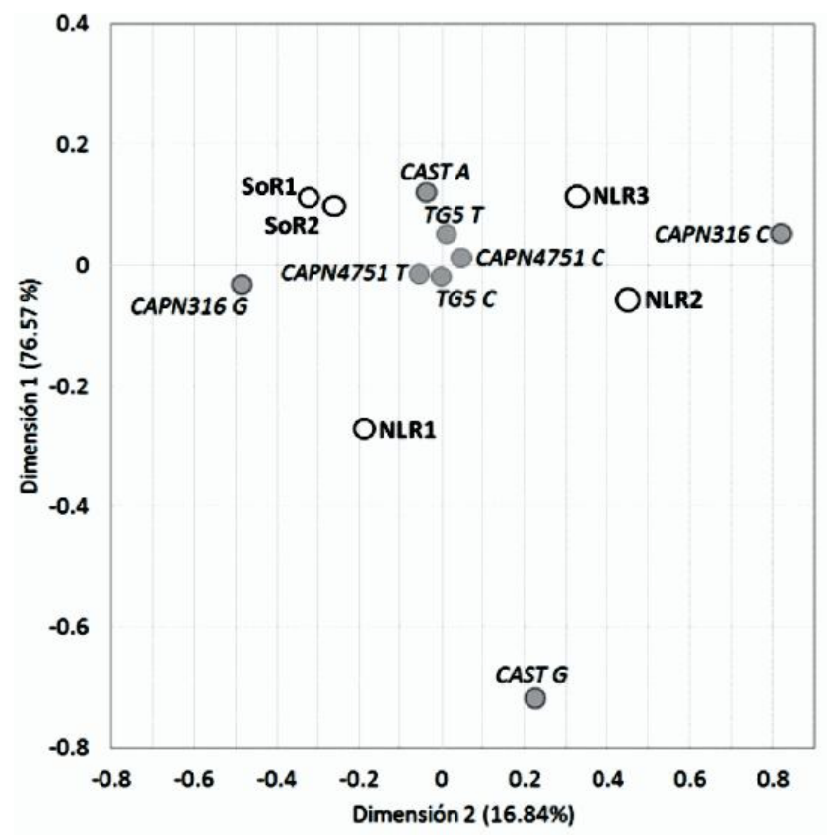

Cuadro 3. Heterocigocidades esperadas y observadas para los marcadores de calidad de la carne Table 3. Observed and expected heterozygosities for meat quality markers

\begin{tabular}{|c|c|c|c|c|c|c|c|c|c|c|c|c|}
\hline \multirow[b]{2}{*}{$\underline{\text { Herd }}$} & \multicolumn{3}{|c|}{ TG5 } & \multicolumn{3}{|c|}{ CAPN1-316 } & \multicolumn{3}{|c|}{ CAPN1-4751 } & \multicolumn{3}{|c|}{ CAST-T1 } \\
\hline & $\mathrm{Ho}$ & $\mathrm{He}$ & $\mathrm{HW}$ & $\mathrm{Ho}$ & $\mathrm{He}$ & $\mathrm{HW}$ & $\mathrm{Ho}$ & $\mathrm{He}$ & $\mathrm{HW}$ & $\mathrm{Ho}$ & $\mathrm{He}$ & $\mathrm{HW}$ \\
\hline SoR1 (83) & 0.169 & 0.329 & $\star * *$ & 0.064 & 0.154 & $\star * \star$ & 0.494 & 0.502 & ns & 0.036 & 0.036 & ns \\
\hline SoR2 (74) & 0.189 & 0.524 & *** & 0.270 & 0.235 & ns & 0.541 & 0.500 & ns & 0.095 & 0.115 & ns \\
\hline NLR1 (79) & 0.397 & 0.377 & ns & 0.266 & 0.268 & ns & 0.532 & 0.503 & ns & 0.474 & 0.434 & ns \\
\hline NLR2 (95) & 0.295 & 0.334 & ns & 0.031 & 0.320 & *** & 0.500 & 0.490 & ns & 0.270 & 0.351 & ns \\
\hline NLR3 (148) & 0.155 & 0.446 & *** & 0.573 & 0.410 & *** & 0.446 & 0.494 & ns & 0.185 & 0.179 & ns \\
\hline
\end{tabular}

$\mathrm{Ho}=$ observed heterozygosity; $\mathrm{He}=$ expected heterozygosity; $\mathrm{HW}=\mathrm{Hardy}-$ Weinberg equilibrium; ns= not significant. 
poblaciones del noreste (NLR2 y NLR3). En todos los casos la desviación fue debida a un déficit de heterocigotos.

\section{DISCUSIÓN}

Enfermedades genéticas

A nivel mundial, las Asociaciones Ganaderas reconocen oficialmente, en las diferentes razas de bovinos, desórdenes genéticos que se reportan en el registro del animal. A través de esta práctica, se obtiene importante información que la Asociación Ganadera puede hacer disponible a los compradores de animales y de semen, lo que hace posible su exclusión como reproductor o manejo adecuado dentro del hato, mientras que para la Asociación es una forma de controlar la diseminación y lograr la eventual eliminación de los portadores.

Se ha descrito que el fenotipo doble músculo muestra diferencias en la frecuencia entre razas; esto se puede deber a que durante muchas generaciones los rasgos que se relacionan a este fenotipo tienen intensidades de selección que dependen de los objetivos productivos del hato o población donde se presenta(4). De acuerdo a diferentes reportes, la presencia del doble músculo en la raza Charolais se ha promovido principalmente para obtener portadores en cruzas terminales $(12,13,14)$. En México, productores de la raza Charolais reportan que han optado por limitar e incluso eliminar su presencia en el hato, debido a los problemas de distocia. Para lograrlo, ellos se han basado en la inspección visual de los animales buscando las características del fenotipo DM.

En este estudio se encontraron frecuencias alélicas de 0 a $14 \%$ y todos los animales fueron portadores heterocigotos. La presencia del alelo en las poblaciones de Charolais analizadas puede ser consecuencia de que los animales heterocigotos o portadores del alelo son difíciles de diferenciar de los portadores normales, ya que los portadores heterocigotos no muestran el marcado desarrollo muscular
Frequency of the DM phenotype varies among different cattle breeds. This is because the traits associated to this phenotype have been selected for at varying intensities depending on the production goals of a given herd or population(4). In the Charolais breed, the DM phenotype has been promoted mainly to produce carriers in terminal crosses $(12,13,14)$. Due to problems with dystocia, Charolais producers in Mexico have opted to reduce and even eliminate DM presence from their herds. Visual examination of animals is used to identify DM phenotype traits and manage them accordingly to each herd objective.

Allele frequencies in the present data ranged from 0 to $14 \%$ and all carriers were heterozygotic. Presence of the allele in the analyzed Charolais populations could be due to the difficulty of identifying carrier animals from normal animals, because Charolais DM carriers do not exhibit the marked muscle development characteristic of the phenotype(15). In these situations, DNA tests are a valuable tool because they generate data that can assist producers in making decisions based on herd objectives, taking into account the productive and reproductive advantages and disadvantages of the DM condition.

Carriers were also identified of the marker associated with GDS-V. This muscular disease is induced by a point mutation in the glycogen phosphorylase enzyme gene that causes intolerance to exercise, myalgia and recurrent myoglobinuria. Very little data is available on the prevalence of this recessive disorder in cattle, and most reports in Charolais animals are of carriers(16). In a study of a carrier family in Charolais herds in New Zealand, presence of the allele was found to most probably be caused by import of animals from England and the United States(17). The present study is the first report of carriers of the GDS-V-associated marker in Charolais cattle in Mexico. Of particular note is identification of a male carrier that currently has at least 38 registered progeny (34 males, 4 females) in the Asociación Charolais 
que es característico de los animales DM(15). En situaciones como ésta, las pruebas de ADN representan una herramienta valiosa, ya que esta información dará al productor la oportunidad de decidir y manejar, de acuerdo al objetivo del hato, las ventajas y desventajas productivas y reproductivas asociadas a la presencia de esta condición genética.

En el estudio también se encontraron portadores del marcador asociado a la enfermedad de almacenamiento del glucógeno tipo V. Esta es una enfermedad muscular inducida por una mutación puntual en el gen de la enzima glucógeno fosforilasa, lo que causa intolerancia al ejercicio, mialgia y mioglobinuria recurrente. Son pocos los reportes sobre la prevalencia de este desorden recesivo en ganado bovino, y en ganado Charolais la mayoría de los reportes son casos de portadores(16). Jolly et al(17) reportaron la presencia de una familia portadora en hatos de ganado Charolais en Nueva Zelanda e identificaron que la presencia del alelo recesivo pudo deberse a importaciones de animales de Inglaterra o América. En México, este es el primer reporte de portadores del marcador asociado a la enfermedad de almacenamiento del glucógeno tipo $\mathrm{V}$ en ganado Charolais mexicano; el caso más relevante de este resultado, es la identificación de un portador macho, el cual a la fecha tiene al menos 38 crías registradas en las bases de datos de la Asociación Charolais HerdBook de Mexico (34 Machos y 4 hembras), y a las cuales a la fecha no se les ha realizado la prueba de ADN para identificar el alelo recesivo. Aun cuando las implicaciones productivas de la enfermedad de almacenamiento del glucógeno tipo $\mathrm{V}$ para animales portadores no han sido reportadas, el efecto de la presencia de portadores en los hatos es potencialmente dañina.

\section{Marcadores asociados a calidad de carne}

En México no se cuenta con amplia información sobre la calidad de la carne de bovinos, esto en parte se debe a que aún no están completamente definidos los criterios para su clasificación(18). Sin embargo, dado que la
HerdBook de Mexico. To date, no DNA tests have been done to identify the recessive gene in these progeny. No reports exist on the productive consequences of GDS- $V$ carriers, but their presence in herds is potentially damaging.

\section{Markers associated with meat quality}

Partially due to lack of completely defined criteria, data on meat quality in beef cattle in Mexico is limited(18). However, the advent of biotechnology in the meat industry now allows application of molecular diagnosis of the genes associated with meat quality. This is an important first step in identifying the allele frequencies of these markers in registered cattle. The production process in Mexico requires that any genetic improvement program begin in the pure cattle breeds. For complex traits such as meat quality, improvement can be expected to appear in cattle for slaughter.

The meat quality markers analyzed here are included in commercial tests for meat tenderness and marbling, which is why the favorable effect of each allele variant has been reported(6). Allelic and genotype frequencies observed in the present study, showed that the herds to have high to medium frequencies of the alleles reported as favorable for the markers CAST-T1 (allele A) and CAPN1-4751 (allele C). The allele reported as unfavorable for the markers CAPN316 and TG5 had the highest frequency (91.5 and $69.1 \%$, respectively).

The values in the present study are similar to those in a study of allele frequencies in French Charolais cattle for the markers CAST-T1 (high frequency) and CAPN316 (low frequency). The two markers of the CAPN1 gene have been reported to explain up to $25 \%$ of genetic variation in meat tenderness(19) and up to $18 \%$ of phenotype variability(6). However, other reports indicate that this effect depends on genetic background and the populations evaluated(20).

Two of the four markers analyzed in the present study were included in a study of young 
aplicación de la biotecnología ha alcanzado a la industria de la carne y el uso del diagnóstico molecular de genes asociados a su calidad están disponibles para los ganaderos, es de interés dar el primer paso para determinar las frecuencias alélicas de estos marcadores en ganado de registro, ya que de acuerdo a la cadena productiva que prevalece en México, cualquier estrategia de mejoramiento genético empieza en las razas puras y para rasgos complejos como la calidad de la carne, se esperaría que el impacto de este mejoramiento se refleje en el ganado de sacrificio.

Los marcadores de calidad de la carne analizados en este estudio están incluidos en las pruebas comerciales para suavidad y marmoleo de la carne, por lo que se ha reportado el efecto favorable de cada variante alélica(6).

De acuerdo a las frecuencias alélicas y genotípicas obtenidas en las poblaciones analizadas, todos los hatos muestran frecuencias de altas a moderadas del alelo reportado como favorable para los marcadores CAST-T1 (alelo A) y CAPN1-4751 (alelo C), mientras que para los marcadores CAPN316 y TG5 el alelo reportado como desfavorable fue el de mayor frecuencia (de 91.5 a $69.1 \%$, respectivamente).

En un estudio realizado en ganado Charolais francés, Allais et al(11) reportaron frecuencias alélicas similares a las encontradas en este trabajo para los marcadores CAST-T1 (alta frecuencia) y CAPN316 (baja frecuencia). Se ha reportado que los dos marcadores del gen CAPN1 explican hasta el $25 \%$ de variación genética en la suavidad de la carne(19) y hasta el $18 \%$ de su variabilidad fenotípica(6); sin embargo otros autores han encontrado que este efecto es dependiente del fondo genético y de las poblaciones donde se evalúa(20).

Recientemente, dos de los cuatro marcadores analizados en este trabajo han sido estudiados en toretes de ganado Charolais Mexicano(21)
Charolais bulls in Mexico(21). The marker CAPN14751 had a significant effect on rib eye muscle area (REA) and intramuscular fat (IMF) measured by ultrasound, and the marker TG5 tended to associate with yield grade (YG). Research confirming this association, possibly supported by the National Council on Genetic Resources (Consejo Nacional de los Recursos Genéticos - CONARGEN), could help to measure meat quality traits using ultrasound.

The only study to date on the association of phenotypic variables to meat quality markers in Mexico supports a favorable association between markers 4751 and TG5, and the traits of cutting force and marbling(7). However, this study's limited sample size and is not considered as a validation study quantifying the effects of the genotypes of each marker in these traits. In the present study, the frequencies observed for the four studied meat quality markers justify implementation of management strategies aimed at increasing their frequencies, as well as design of studies to evaluate the effect of phenotype in marker-assisted management.

Although genetic differentiation was observed in the studied populations, and deviation was present in the HWE of two loci, it is unlikely that this can be explained by selection for meat quality traits (tenderness and marbling) since these are not included in genetic improvement strategies. The differentiation between the populations in the northwest $(P<0.0001)$ and northeast $(P<0.001)$ could be explained by the source of genetic material used in herd management. Producers in the northwest commented that they use Charolais animals and genetic material from the United States, with almost no influence from European genetic material. In contrast, producers in the northeast primarily use genetic material from France. This coincides with a study evaluating molecular genetic variation in three populations of Charolais cattle in Mexico(22) in which genetic differentiation between populations was a consequence of selection of genetic material for herd management(22). 
encontrándose que el marcador CAPN1-4751 tiene efecto significativo sobre el área del músculo Longissimus dorsi (REA) y grasa intramuscular (IMF) medidos por ultrasonografía; mientras que el marcador TG5 mostró una tendencia de asociación al grado de rendimiento (YG), por lo que estudios para confirmar esta asociación podrían llevarse a cabo con las iniciativas por parte del Consejo Nacional de los Recursos Genéticos (CONARGEN) para medir rasgos de calidad de la carne basándose en ultrasonografía. El único trabajo de asociación con variables fenotípicas con los marcadores de calidad de la carne reportado a la fecha en México(7), apoya la asociación favorable de los marcadores 4751 y TG5 a la fuerza de corte y marmoleo; sin embargo, dado el tamaño de muestra estudiado, no se podría considerar como un estudio de validación que permita cuantificar el efecto de los genotipos de cada marcador sobre estos rasgos. Las frecuencias encontradas para los cuatro marcadores de calidad de la carne en las poblaciones Charolais estudiadas justifican la implementación de estrategias de manejo, tendientes a aumentar su frecuencia, así como para diseñar estudios para evaluar su efecto fenotípico del manejo asistido por marcadores.

Aunque se encontró diferenciación genética en las poblaciones estudiadas y desviación al EHW para dos loci, es improbable que este resultado pueda explicarse por la selección de los rasgos de calidad de la carne (suavidad y marmoleo), ya que estos rasgos no son considerados en las estrategias de mejoramiento genético. Esta diferenciación por regiones (poblaciones del noroeste $(P<0.0001)$ y del noreste $(P<0.001)$ podría explicarse por el origen del material genético con el que se manejan los hatos. De acuerdo con los propietarios de los hatos del noroeste, su ganado es Charolais americano y la influencia de material genético europeo es casi nula, contrario a los tres hatos del noreste que tienen una alta influencia de material genético proveniente principalmente de Francia. Sifuentes-Rincón et al(22) en un estudio para evaluar la variación genética molecular en tres poblaciones mexicanas de ganado Charolais
All four quality markers used in the present study have been validated in the United States as predictors of meat marbling and quality. Commercial services are now available offering DNA tests for these and many other quality and productivity markers in cattle. This opens the possibility of producers or cattle associations employing these tests as tools to support genetic improvement programs, thus avoiding selection of individuals with unfavorable phenotypes. Further research is still needed on the association of these markers with traits in local populations, and validation of these associations to identify and quantify their effects on all traits of interest.

\section{CONCLUSIONS AND IMPLICATIONS}

No DUMP or ASS carriers were identified in the studied populations, showing them to have adequate genetic health. Some carriers of GDS$\checkmark$ were found, highlighting the need for ongoing monitoring, especially of imported semen. Frequencies of the Q204X allele of the MSTN gene varied among herds, perhaps due to the source of genetic material used in herd management. Charolais producers need to understand the advantages and disadvantages of this allele in their herds, and use DNA testing to increase or eliminate it, depending on their production goals. Significant genetic differentiation between herds was present in the loci associated with quality and productivity. The frequencies of the alleles -reported and in some cases validated in the literature- identified in the studied populations and which are known to be favorable for different quality traits support implementation of strategies to confirm their use as a tool to complement genetic improvement programs in the Charolais breed in Mexico.

\section{ACKNOWLEDGEMENTS}

Thank to producers of the five studied Charolais herds and the Asociación Charolais HerdBook de México for providing study materials. 
utilizando marcadores microsatélites, encontraron diferenciación genética en la población estudiada, la cual fue seleccionada con base al material genético con el que se mejoraban las poblaciones, por lo que concluyen que la estructura encontrada es consecuencia de este manejo.

Como se expuso, los cuatro marcadores de calidad utilizados en este estudio, han sido validados en EU como predictores de la calidad y marmoleo de la carne. Existen actualmente compañías comerciales que ofertan pruebas de ADN para estos y muchos otros marcadores de calidad y productividad en ganado bovino, lo que ha abierto la posibilidad para que ganaderos - Asociaciones ganaderas las incluyan como herramienta para apoyar los programas de mejoramiento genético, evitando la selección de individuos con genotipos no favorables; sin embargo, es muy importante hacer estudios de asociación y validación de los marcadores en las poblaciones locales, a fin de precisar y cuantificar sus efectos en todos los rasgos de interés.

\section{CONCLUSIONES E IMPLICACIONES}

De acuerdo a los resultados, la salud genética para la población estudiada es adecuada para los desórdenes recesivos UMP y ASS ya que no se detectaron portadores. Se recomienda el monitoreo de la enfermedad de almacenamiento de glucógeno donde se encontraron algunos portadores; este monitoreo es importante sobre todo en los casos de importación de semen. Respecto al alelo Q204X del gen MSTN, sus frecuencias varían entre hatos y podrían relacionarse con el origen del material genético que se utiliza en ellos; es muy importante que los criadores de esta raza reconozcan las ventajas y desventajas de la presencia de este alelo en los hatos y utilicen la prueba de ADN para aumentar o eliminar su presencia en sus poblaciones. Las poblaciones estudiadas mostraron diferenciación genética significativa cuando se evaluó con los loci asociados a rasgos de calidad y productividad. Las frecuencias
Financial support from FORDECYT 116152 and FOMIX Tamaulipas 177460.

End of english version

encontradas en la población de estudio de los alelos previamente reportados y en algunos casos validados en la literatura como favorables para los diferentes rasgos de calidad, justifican la implementación de estrategias para confirmar su utilidad como herramienta para complementar los programas de mejoramiento genético de la raza Charolais en México.

\section{AGRADECIMIENTOS}

Se agradece el apoyo brindado por los productores de los cuatro hatos de ganado Charolais y la Asociación Charolais HerdBook de México, para la obtención del material de estudio.

Proyecto apoyado por fondos FORDECYT 116152 y FOMIX Tamaulipas 177460.

\section{LITERATURA CITADA}

1. I beagha-Awemu EM, Kgwatalala P, Zhao X. A critical analysis of production-associated DNA polymorphisms in the genes of cattle, goat, sheep, and pig. Mamm Genome 2008; (19):591-617.

2. Strauss S. Genomics goes bovine. Nature Biotechnology 2010; 28: 6:540-543.

3. Ebegbulem VN, Ozung PO. Application of molecular markers in farm animal improvement: Prospects and challenges. Online J Anim Feed Res 2013;3(3):149-152.

4. Fiems LO. Double muscling in cattle: Genes, husbandry, carcasses and meat. Animal 2012;2:472-506.

5. Citek J, Rehout V, Hajkova J, Pavkova J. Monitoring of the genetic health of cattle in the Czech Republic. Vet Med Czech 2006;51(6):333-339.

6. Van Eenennaam AL, Li J, Thallman RM, Quaas RL, Dikeman ME, Gill CA, et al. Validation of comercial DNA test for quantitative beef quality traits. J Anim Sci 2007; (85):891-900.

7. Bonilla CA, Rubio MS, Sifuentes AM, Parra-Bracamonte GM, Arellano WW, Méndez MRD, et al. Association of CAPN1 
316. CAPN1-4751 and TG5 markers with Mexican bovine meat quality traits. Genet Mol Res 2010;9(4):2395-2405.

8. Barendse W, Bunch R, Thomas M, Armitage S, Baud S, Donaldson N. The TG5 thyroglobulin gene test for marbling quantitative trait loci evaluated in feedlot cattle. Aust J Exp Agric 2004; (44):669-674.

9. Kalinowski ST, Taper ML, Marshall, TC. Revising how the computer program CERVUS accommodates genotyping error increases success in paternity assignment. Mol Ecol 2007; 6: 1099-1106.

10. Rousset, F. Genepop'007: a complete reimplementation of the Genepop software for Windows and Linux. Mol Ecol Resour 2008; 8:103-106.

11. Allais S, Levéziel H, Payet-Duprat N, Hocquette JF, Lepetit J, Rousset S, et al. The two mutations, Q204X and nt821, of the myostatin gene affect carcass and meat quality in young heterozygous bulls of French beef breeds. J Anim Sci 2010; (88): 446-454.

12. Parra-Bracamonte GM, Sifuentes-Rincón AM, Arellano-Vera W, Almanza-González A, De la Rosa-Reyna XF. Tipificación de tres marcadores genéticos de caracteres de importancia comercial en ganado Charolais: implicaciones en la ganadería para carne en México. Rev Colomb Cienc Pecu 2009; (22):257-266.

13. Phocas F. Genetic analysis of breeding traits in a Charolais cattle population segregating an inactive myostatin allele. J
Anim Sci 2009; (87):1865-1871.

14. Dhuyvetter MJ, Frahm RR, Marshall MD. Comparision of Charolais and Limousin as terminal cross sire breeds. J Anim Sci 1985; (4):935-941.

15. Keele JW, Fahrenkrug SC. Optimun mating systems for the myostatin locus in cattle. J Anim Sci 2001;79:2016-2022.

16. Distl $O$. The use of molecular genetics in eliminating of inherited anomalies in cattle. Arch Tierz Dummerstorf 2005; 48: (3):209-218.

17. Jolly RD, McSporran KD y J ohnstone AC. Myophosphorylase deficiency (glycogen storage disease Type V) in Charolais cattle, N Z Vet J 2004;52(1):50-50.

18. Delgado EJ, Rubio MS, Iturbe FA, Méndez RD, Cassís L, Rosiles R. Composition and quality of Mexican and imported retail beef in Mexico. Meat Sci 2005;(69):465-471

19. Allan MF, Smith TPL. Present and future applications of DNA technologies to improve beef production. Meat Sci 2008; (80): 79-85.

20. Rousset LS, Denoyelle, Bernard-Capel C. Renand ,Allais $\underline{S}$, Journaux $L$, et al. Three French beef breeds effects of polymorphisms in the calpastatin and ì-calpain genes on meat tenderness. J Anim Sci 2011;89:1-11.

21. Muñoz-Mejía CY, Parra-Bracamonte GM, Sifuentes-Rincón AM, Martínez-González JC, López-Bustamante LA, ArellanoVera W, et al. Indicadores genómicos y fenotípicos de calidad de la carne en bovinos Charolais de México. Rev Colomb Cienc Pecu 2012; (25):210-219.

22. Sifuentes-Rincón AM, Puentes-Montiel H. Parra-Bracamonte M. Assesment of genetic structure in Mexican Charolais herds using microsatellite markers. Electron J Biotechnol 2007; 10:4-15. 
